\title{
END CONSUMERS' BUYING HABITS IN BEER MARKET: CASE OF LATVIA
}

\author{
Ieva Brence ${ }^{1}$, Associate professor/ Dr.sc.administr.; Ieva Avotina ${ }^{2}$ \\ ${ }_{1,2}$ RISEBA University of Applied Sciences
}

\begin{abstract}
Beer is the most consumed alcoholic beverage in Latvia (SRS, Excise goods movement statistics and results, 2016), nevertheless, beer consumption trends and consumer behaviour is not often studied subject in this field.

Aim of the research is to explore end-consumer beer buying habits in Latvia. The research involves surveying Riga's end consumers (age 25 - 40) with income exceeding the average wage in Latvia (EUR 1000 gross). The research results can be applied to the same target groups in other Latvia's regions. The research results will be beneficial for further promoting beer production in the market and finding the right target audience.

The study raised following questions: 1 )What factors influence consumers beer choice and what role plays gender in it; 2)What are the beer consumption particularities and trends among consumers.

To answer the questions, theoretical analysis was accompanied with Riga's inhabitants' survey. Research methods involve calculation of reliability of Cronbach's alpha; Kolmogorov Smirnov Z criterion; Descriptive Statistics Central Trend Indicators; Concluding statistics - T significance indicator were used. The research object: beer market end-consumers. The research concentrates only on the consumers having consumed beer.

Findings show that gender has an impact on beer consumption habits. Research results prove that target audience of beer are male ( $55 \%$ of the males and $18 \%$ of the females report to consume beer every week), males are more open minded towards new beer product trial, and more often pay attention on informative articles about beer in media, they orientate better in beer industry. Beer has expressively seasonal character, it is more consumed during summer - this aspect is especially characterised among women and is expressively associated as a thirst refreshing beverage. Beer is often bought as a gift. Quality and price relation becomes more important in the group surveyed - people start paying more attention to quality, cheaper price or discounts reporting as not the most significant aspect when buying beer.
\end{abstract}

Key words: beer, consumption, gender differences, cognitive, behavioural trends.

JEL code: Q13.

\section{Introduction}

Beer is the most consumed alcohol in Latvia (statistics and results of the SRS Excise Movement Section, 2018), but despite this, beer consumption trends are a little studied issue, especially consumer behaviour in this field and factors influencing purchase choices. There is also a limited amount of available information about the market in beer in Latvia and the current situation.

The aim of the research is to explore end-consumer beer buying habits in Latvia.

Research tasks: basing on the analysis of the literature on consumers' behaviour, to conduct research on consumer buying habits and factors influencing choice of beer products. The following research questions are addressed: 1)What factors influence consumers beer choice and what role plays gender in it; 2)What are the beer consumption particularities and trends among consumers.

Research methodology: a survey of Riga's inhabitants was carried out with a quasi-experimental design, since the variables are not affected. A descriptive study of the relationship research, which seeks to differentiate beer consumption patterns between male and female sample groups was performed. Limitation - Respondents were aged 25 - 40, they live in or around Riga, gross income - EUR 1000 or more. The group was chosen, taken into account the gross average salary in Riga EUR 1085 (Central Statistical Bureau, 2018).

\footnotetext{
${ }^{1}$ Corresponding author. Tel.: +371 26363506, E-mail address: ieva.brence@riseba.Iv
} 
The total number of respondents is 154 with an average age of 34 years, among which 89 men with an average age of 34.3 years and 65 women with an average age of 34.5 years.

Calculation of reliability of Cronbach's alpha; Kolmogorov Smirnov Z criterion was performed; Descriptive Statistics - Central Trend Indicators; Concluding statistics - T significance indicator were used.

\section{Research results and discussion}

\section{Beer consumption trends - previous research works}

The data on the existence of beer is very old, first fixed around the year 1800, when the anthem of the Sumerian Beer goddess was engraved on the plate, having the first signs of brewing beer to appear (CraftBeer, 2018). In the last decade the brewing style like craft beer brewed has developed, regarded as beer produced by small breweries. Unfortunately, this designation does not have a clear definition except for the United States - craft beer is a small, independent and traditional beer brewery, in the small sense, producing less than 6 mill. barrel ( 117 L / barrel, ie $72 \mathrm{ml} \mathrm{L}$ ) beer per year, independent - $25 \%$ of the brewery is owned or controlled by a person who is not alder himself (Dredge, 2013). This definition it is difficult to apply to the Latvian market, as the consumption of beer in Latvia during the whole year is only about twice as big as the above-mentioned example, e.g., in 2015 it was 152 million (Statistics and results of the SRS Excise List of goods division, 2018).

Next, it's possible to divide both lager and ale style beer into even more detailed categories, such as beer styles, which can often be found on labels on beer bottles on store shelves (Beer Cartel.com, 2018). Factors influencing consumer choice and consumption patterns can be divided into two categories: beer properties and factors associated with the shopping process (Aquilani, Laureti, Poponi, Secondi, 2014). More than 50 years ago, Alison and Uhl (Allison and Uhl, 1964, cited by Aquilani, Lauret, Poponi, and Secondi, 2014) found that consumers were not able to recognize the taste of a particular beer brand, despite the information they received about this brand. In contrast, Sester, Dacremont, Deroy, and Valentine (Sester, Dacremont, Deroy, Valentin, 2013, quoted by Aquilani, Lauret, Poponi, and Second, 2014) determined that past consumer experience has a bearing on today's choice of motivation, which in turn depends on the brand's influence, received stimuli, psychological expectations. Consumers often have very clear expectations about taste and they expect certain aromas, such as bitterness, texture characteristics such as bubbles, or psychological quality - thirst-quenching. A beer can be rejected if it does not meet this expectation.

Today's consumer choice for beer is largely determined by the discovery of new flavors, quality searches, as well as product mastery. These factors gradually transform consumer habits and shopping behavior (Aquilani, Lauret, Poponi, Secondi, 2014). In the case of packaging, $16.2 \%$ of respondents preferred beer in a glass bottle, while $17.4 \%$ in the beer jar. Commercial beer consumers recognized quality as the most important factor with an average arithmetic score of 4.13 (of 6) and an aroma of 3.92 points (Aquilani, Lauret, Poponi, Secondi, 2014).

Deconinks and Swinnen (Deconinck, Swinnen, 2013) have examined people's' role in increasing beer consumption in Russia, where it has tripled between 1996 and 2007, becoming the most important alcoholic beverage and making Russia the third largest beer market in the world, ranking behind China and the United States (Deconinck, Swinnen, 2013). In 2007, beer consumption per capita in Russia grew to 80L - a comparison, in Latvia in 2015 it was almost 77L per 1 resident (Statistics and results of the SRS Excise List of goods division, 2016). As one of the reasons the 
authors of the study mention a significant increase in the quality of beer as well as active marketing activities and advertising beer. The study uses Russian Longitudinal Monitoring Survey data, a survey conducted in Russia each year and includes an average of 8,000 respondents from 400 Russian districts, covering 8 of its regions. As a result, the authors of the study found that peers played a significant role as a "transition mechanism", persuading consumers to start consuming beer (switching from vodka to it). Conversely, changes in prices and revenues from respondents have played a minor role (Deconinck, Swinnen, 2013).

In October 2015, the Trial Panel (2015), specializing in rapid commodity research, carried out a fraud trial in France using the Lovemark method to identify and measure emotional interactions between brands and consumers. The study, basing on 300 interviewed respondents, found that the French market is complex and fragmented, with 3 brand divisions, which stirred up completely different emotional ties to consumers. First, a group of brands (Desperados, Leffe and 1664) showed an intense, strong emotional connection with the consumer. There was a group of brands that raised respect and dignity in consumers even in the long run, but at the same time there was a weak emotional link between the brands (Heineken, Pelforth and Grimbergen). Finally, there was a large group of consumer brands, where No one had a differentiated emotional connection with the consumer (TrialPanel, 2015). The study also found that the French market is most likely to have a low emotional differentiation between the brands offered on the market, thus leaving a certain margin of growth and development, which currently has only some brands (TrialPanel, 2015). Taking into account the previous research results, a research on the beer consumption trends in Riga has been performed.

\section{Beer consumption trends in Riga}

Based on the analysis of scientific literature carried out in the previous sections, a survey of Riga inhabitants was carried out with a quasi-experimental design. In the survey, the consumption patterns of beer were calculated for consumers. A descriptive study of the relationship research, which seeks to differentiate beer consumption patterns between male and female sample groups. Respondents live in or around Riga, gross income - EUR 1,000 and more. A quantitative research strategy was selected for conducting the research, aggregating and analysing both primary and secondary data. The authors of the primary data collection used a survey based on the critical analysis of social psychology and marketing theory as well as the analysis of secondary data and information obtained from the organization's research. The survey as a whole consists of 33 questions, 27 of them formulated in the form of an assertion, grouped into 3 scales - affirmative, behavioral and cognitive, 5 questions with a choice of answers and 2 open-ended questions, where the respondent has the opportunity to write his or her answer. The current paper presents the behavioral and cognitive research results. The questionnaire was elaborated, studying number of information sources (Aldaris.Iv, 2018, Anandan, 2009, Brasini and Tassinari, 2003, Cesualus.lv, 2018, Craft Beer.com, 2018, Dzeru alu, 2009, Gosa, 2003, Hajdu, 2013, Martin and Schouten, 2012, TrialPanel, 2015, Weinstein, 2014, World Drinks Awards, 2016). The total number of respondents was 154 with an average age of 34 years, among which 89 men with an average age of 34.3 years and 65 women with an average age of 34.5 years. All the respondents were Latvian speaking. For the apparent validity check, two independent evaluators were used, who were asked to consult the survey and give an assessment of whether the questionnaire questions are clearly clear and understandable. Two experts were also asked to provide an opinion on content validity. The 
evaluators acknowledged that the content matched the given topic. The questionnaire was elaborated in Latvian using the Likert scale, coded as follows: 1 - agree, 2 - rather agree, 3 - rather disagree, 4 - disagree. The survey questions are based on scales that measure certain factors.'

Table 1

\section{Characterisation of the questionnaire}

\begin{tabular}{|c|c|c|}
\hline \multicolumn{2}{|c|}{ Scale } & Description \\
\hline Scale & Behavioral & $\begin{array}{c}\text { Relates to the behavioral component of attitudes or the influence of respondent } \\
\text { attitudes on their behavior towards beer products }\end{array}$ \\
\hline Scale & Cognitive & $\begin{array}{c}\text { Refers to the cognitive component of the attitude, i.e. the knowledge and attitudes of } \\
\text { respondents regarding the beer industry }\end{array}$ \\
\hline
\end{tabular}

The data obtained in the surveys were analysed using quantitative statistical research methods as well as mathematical statistical methods, calculating the reliability of the data, or the Cronbach a coefficient, data adequacy to the normal distribution, determining the data of the central trend indicators. At most, the Cronbach's a coefficient is above 0.6 , which indicates that the data is reliable.

Table 2

Characterisation of the internal consistency

\begin{tabular}{|l|c|c|}
\hline \multicolumn{1}{|c|}{ Scales } & Cronbach a & Number of scales \\
\hline Total & 0.64 & 26 \\
\hline Total females & 0.70 & 26 \\
\hline Total - males & 0.62 & 26 \\
\hline
\end{tabular}

Source: author's calculations based on the survey, $n=154$

The Kolmogorov-Smirnov $Z$ criterion calculation was made to determine the correspondence of the survey data to the normal distribution. This calculation uses the start data table. Significance is one of the criteria for determining the normal distribution of data.

Table 3

Characterisation of the internal consistency

\begin{tabular}{|l|c|c|c|c|}
\hline \multicolumn{1}{|c|}{ Measure } & $\begin{array}{c}\text { Behavioral } \\
\text { (males) }\end{array}$ & $\begin{array}{c}\text { Cognitive } \\
\text { (males) }\end{array}$ & $\begin{array}{c}\text { Behavioral } \\
\text { (females) }\end{array}$ & $\begin{array}{c}\text { Cognitive } \\
\text { (females) }\end{array}$ \\
\hline $\mathbf{N}$ & 89 & 89 & 65 & 65 \\
\hline Kolmogoroff-Smirnoff Z criteria & 1.193 & 1.017 & .964 & .914 \\
\hline Significance & .116 & .252 & .311 & .373 \\
\hline
\end{tabular}

Source: author's calculations based on the survey, $n=154$

Analysing the K-Smirnov $Z$ index, it is concluded that the significance of all scales is greater than 0.05 , thus, it corresponds to the normal distribution and is representative. The central trend indicators for the male group - the arithmetic average, the median, the mode are close to their values, so the sample size is sufficient to measure the results. The asymmetry coefficient for the cognitive scale is positive, hence the results tend to be lower values. In contrast, the behavioral scale is negative, hence the results tend to be higher values.

Overall characteristics of the survey results

\begin{tabular}{|l|c|c|c|c|}
\hline \multicolumn{1}{|c|}{ Measure } & $\begin{array}{c}\text { Behavioral } \\
\text { (males) }\end{array}$ & $\begin{array}{c}\text { Cognitive } \\
\text { (males) }\end{array}$ & $\begin{array}{c}\text { Behavioral } \\
\text { (females) }\end{array}$ & $\begin{array}{c}\text { Cognitive } \\
\text { (females) }\end{array}$ \\
\hline Mean & 12.11 & 13.85 & 12.03 & 15.23 \\
\hline Median & 13.00 & 13.00 & 12.00 & 15.00 \\
\hline Mode & 13.00 & 13.00 & 12.00 & 17.00 \\
\hline Standard deviation & 2.89 & 3.30 & 2.30 & 3.72 \\
\hline Skewness & -.16 & .32 & .08 & .17 \\
\hline Kurtosis & -.35 & -.16 & .36 & -.03 \\
\hline
\end{tabular}


Analysing the results of the women's group (Table 4), the central trend indicators (arithmetical mean, median, mode) are comparatively similar. The skewness for all scales is positive, so the results tend to be lower values. Behavioral scales are positive, the results tend to group around the arithmetic mean. In contrast, the cognitive scale is negative. When examining whether there are differences between groups of women and men in the two scales in the independent t-test, it is evident from the obtained indicators that they exist on the cognitive scale, since the signification rate is lower than 0.05 .

Table 5

Sig. (2-tailed) results

\begin{tabular}{|l|c|c|c|c|}
\hline \multicolumn{1}{|c|}{ Scales } & $\mathbf{t}$ & Sig. (2-tailed) & Males - mean & Feales - mean \\
\hline Behavioral & .17 & .86 & 12.11 & 12.03 \\
\hline Cognitive & $\mathbf{- 2 . 4}$ & $\mathbf{. 0 2}$ & 13.85 & 15.23 \\
\hline
\end{tabular}

Source: author's calculations based on the survey, $n=154$

Also, looking at the differences between the tendencies in the central trends of men's and women's groups, it is seen that they are higher in the group of women in both of these scales - in cognitive terms. It points to the fact that women have a more emotional approach to decision-making, and this group is more reliant on greetings, more evaluation of different criteria before making a decision. The behavioral scale examines the consumer's attitude to beer, its peculiarities of consumption, the new beer position, its visual appearance and the impact on future behavior, the impact on the acquisition process. The main research results are presented in the table.

Table 6

Descriptive statistics of the survey results

\begin{tabular}{|c|c|c|c|c|c|}
\hline & Gender & $\begin{array}{c}\text { Fully agree } \\
(\%)\end{array}$ & $\begin{array}{c}\text { More agree } \\
(\%)\end{array}$ & $\begin{array}{c}\text { More disagree } \\
(\%)\end{array}$ & $\begin{array}{c}\text { Fully disagree } \\
(\%)\end{array}$ \\
\hline \multirow{2}{*}{$\begin{array}{l}\text { I purchase the beer } \\
\text { having a discount }\end{array}$} & $\mathrm{F}$ & 6 & 23 & 22 & 49 \\
\hline & $M$ & 6 & 19 & 30 & 45 \\
\hline \multirow{2}{*}{$\begin{array}{l}\text { I am attracted by the } \\
\text { etiquette or special } \\
\text { design of the bottle }\end{array}$} & $\mathrm{F}$ & 38 & 31 & 23 & 8 \\
\hline & $M$ & 20 & 36 & 26 & 18 \\
\hline \multirow{2}{*}{$\begin{array}{l}\text { I am searching for } \\
\text { information before } \\
\text { buying beer }\end{array}$} & $\mathrm{F}$ & 2 & 28 & 40 & 31 \\
\hline & $M$ & 8 & 24 & 35 & 34 \\
\hline \multirow{2}{*}{$\begin{array}{l}\text { I have read articles or } \\
\text { other information } \\
\text { about beer }\end{array}$} & $\mathrm{F}$ & 42 & 31 & 15 & 12 \\
\hline & $M$ & 61 & 28 & 7 & 4 \\
\hline \multirow{2}{*}{$\begin{array}{l}\text { I know the } \\
\text { ingredients used for } \\
\text { producing beer }\end{array}$} & $\mathrm{F}$ & 25 & 48 & 17 & 11 \\
\hline & $M$ & 42 & 38 & 12 & 8 \\
\hline \multirow{2}{*}{$\begin{array}{l}\text { I like buying and } \\
\text { using new, not known } \\
\text { beer }\end{array}$} & $\mathrm{F}$ & 28 & 32 & 34 & 6 \\
\hline & $M$ & 38 & 39 & 19 & 3 \\
\hline \multirow{2}{*}{$\begin{array}{l}\text { I consume beer every } \\
\text { week }\end{array}$} & $\mathrm{F}$ & 12 & 17 & 23 & 48 \\
\hline & $M$ & 55 & 18 & 12 & 15 \\
\hline
\end{tabular}

Source: author's calculations based on the survey, $n=154$

The impact of the price action on the purchase is uneven and unobtrusive, as can be seen in the results of the survey, where $71 \%$ of women and $75 \%$ of men note that they partially disagree or disagree with the statement that they only buy the beer that is currently being discounted.

Researching the importance of beer etiquette and bottle design as a whole, as it affects the perception of the consumer as a whole, among respondents the role of aesthetics is more pronounced among women, since more than a third is $39 \%$ strongly agrees with the statement that a special visual beer design attracts more of them, while men only agree with the statement of only $20 \%$. 
However, the majority of respondents agreed to the statement as a whole, so it can be concluded that the visual and aesthetic presentation of the product has a significant impact on the choice of beer in both sexes, more pronounced among women.

When looking at whether respondents tend to read articles about beer, a convincing majority agrees with this statement. The respondents of the men's group have responded more clearly and convincingly, but according to the author, this is due to the fact that the beer and related issues for men are nevertheless closer to the male audience, as evidenced by the results of the 3rd issue of beer consumption.

Conclusions from the results of the questionnaire on the behavioral scales - the prevalence of men consumes beer every week, while women do so less often. A preliminary study of the supply of beer products does not take place practically, especially among the group of men. The price oat the time of purchase of beer is not determinative, the primary role plays the purchase choice. For the visual aesthetic beer presentation women play a more important role, yet it is also not too insignificant for men. Men also recognize that they are learning about new beer products from friends, relatives who point to "mouth-to-mouth" ads.

Cognitive scale examines the knowledge of the respondents, the experience of the beer, as well as the views and opinions of the beer, along with how this knowledge influences the opinions of these respondents. When researching whether before the purchase of beer respondents tend to collect additional information about the chosen or current brand, respondents from both groups answered very similarly - they mostly do not agree with this statement. A relatively small proportion, only about $30 \%$ of whom have indicated that they agree. This suggests that respondents rely on existing information that is available to them and known when choosing to choose one or another brand of beer. When it comes to knowing the knowledge about the composition of beer, most respondents note that they agree they are familiar with the ingredients used in beer. However, looking deeper into the responses and results of respondents, it is observed that men are much more confident about this knowledge, as $42 \%$ of them strongly agree with this statement, while full confidence among female respondents is only 25 . By studying how much the respondents are trying to test new and unknown beers, a greater proportion of men, $77 \%$ said they are happy to do so, which is $17 \%$ more than that of women. Here, according to the author, parallels can be drawn with more pronounced beer consumption and the general interest in beer among men, so they are more open to novelty trials and experiments. Since women are less likely to use beer, they may prefer proven values.

Conclusions about the results of the cognitive scale questionnaire: before the purchase of beer, most respondents do not collect information about the chosen brand; men are more confident in their knowledge of the composition of beer as women; Men are more likely to know what craft beer is, while women do not label this sign; a greater predominance of men as women has at least once visited a brewery; men are more open to testing new beers than women, however, in both groups the proportion is large enough for experiments; expressed dominance among respondents for the purchase of beer as a gift, as well as for the purpose of treating someone; the reliability of Latvian beers is higher than that of foreign ones; 3 cups of 0.5 litres of beer and more than men are considered acceptable, most women are inclined to think so. 


\section{Conclusions, proposals, recommendations}

1) Product quality plays an increasingly important role in consumer purchasing choices, leaving the importance of discounts in the secondary plane. Both women and men are quite aware of the price they are willing to pay for beer production.

2) The visual design of the product is more important for women, if compared to males.

3) Respondents in the men's group prefer to know the beer industry better, both in terms of beer production processes and the essence of craft beer.

4) Men are more open to trying new beers than women, but in both groups the proportion is large enough for experiments.

\section{Bibliography}

1. Aldaris.Iv. (2018). Par alus daritavu - Carlsberg grupa. Retrieved: http://www.aldaris.Iv/lv/par-alusdaritavu/carlsberg-grupa. Access: 01.02.2019.

2. Anandan C. (2009). Product Management, 2nd edition. [e-book] New Delhi: Tata McGraw-Hill Education Private Limited. Retrieved: https://books.google.Iv. Access: 01.12.2019.

3. Aquilani B., Laureti T., Poponi S., Secondi L. (2014). Beer Choice and Consumption Determinants When Craft Beers Are Tasted. Food Quality and Preference.

4. Beer Cartel.com. (2018). Difference Between Ale and Lager Beer Styles. Retrieved: http://www.beercartel.com.au/blog/the-difference-between-ales-vs-lagers-explained/. Access: 01.02.2019.

5. Brasini S., Tassinari G. (2003). The Impact of Brand Loyalty and Promotions on Consumer Behaviour. Retrieved: http://sa-ijas.stat.unipd.it/sites/sa-ijas.stat.unipd.it/files/433-453.pdf. Access: 01.12.2018.

6. Brewers Association.org . (2016). Craft Beer History. Retrieved: https://www.brewersassociation.org/brewers-association/history/history-of-craft-brewing/. Access: 01.12.2018.

7. Central Statistical Bureau. (2018). The Average Wage in Latvia. Retrieved: http://data.csb.gov.Iv/pxweb/Iv/Sociala/Sociala_ikgad_dsamaksa/DS0010_euro.px/table/tableViewLayou $\mathrm{t} 1 /$ ?rxid=89fa53c2-5ff7-456f-aae4-c4274cf3b2aa. Access: 01.12.2018.

8. Cesualus.Iv. (2018). Retrieved: http://www.cesualus.Iv/par-mums/olvi-grupa/. Access: 01.12.2018.

9. Craft Beer.com. (2018). History of Beer. Retriewed: http://www.craftbeer.com/the-beverage/history-ofbeer/timeline. Access: 01.12.2018.

10. Deconinck K., Swinnen J. (2013). Peer Effects and the Rise of Beer in Russia. Food policy [e-journal].

11. Dredge M. (2013). Craft Beer World: A Guide to Over 350 of the Finest Beers Known to Man. New York: Ryland Peters \& Small Ltd.

12. Dzeru alu. (2009). Labs alus blogs. Alus tradicijas Latvija. Retrieved: http://labsalus.Iv/alus-tradicijaslatvija. Access: 01.12.2018.

13. Goša Z. (2003). Statistika. Riga: Izdevejs „Izglitibas soli”, iespiests „Jumis”, (c) Latvijas Universitate.

14. Hajdu N. (2013). Strategic and Operative Marketing Controlling. Club of Economics in Miscolc. Retrieved: https://www.google.Iv/url?sa $=t \& r c t=j \& q=\& e s r c=s \&$ source $=$ web\&cd $=6 \& c a d=r j a \& u a c t=8 \& v e d=0$ ahUKEwix $1 \mathrm{a}$ 2zsdrQAhXDdCwKHQSDCagQFggOMAU\&url=http \%3A \%2F \%2Ftmp.gtk.unimiskolc.hu \%2Fvolumes \%2F2013 \%2F01 \%2FTMP_2013_01_03_Hajdu_N.pdf\&usg=AFQjCNEFAI7GgKLKFs QhRa9DCumBQM5Q8A\&sig2=cqHCmIrfWFRAf-QHDoddVQ\&bvm=bv.139782543,d.bGg. Access: 01.12.2018.

15. Martin D., Schouten J. (2012). Sustainable Marketing. USA, New Jersey: Pearson Education, Inc., publishing as Prentice Hal.

16. State Revenue Service of the Republic of Latvia, Excise Data. Retrieved: https://www.vid.gov.Iv/default. aspx?tabid=11\&id=402\&hl=1\&lIzveleId=1551\&periodsId=7692. Access: 01.12.2018.

17. TrialPanel, 2015. Desperados and Leffe the Beer Brands That Have the Strongest Emotional Connection With the Consumer. Retrieved: http://trialpanel.com/desperados-and-leffe-the-beer-brands-that-have-thestrongest-emotional-connection-with-the-consumer/?lang=en. Access: 10.12.2018.

18. Weinstein A. (2014). Defining Your Market. [e-book]. New York: Routledge. Google books. Retrieved: http://booksgoogle.com. Access: 14.12.2018.

19. World Drinks Awards. (2016). Search For the World's Best Drinks: Leffe. Retrieved: http://www.worlddrinksawards.com/search/?q=leffe\&w=be. Access: 15.12.2018. 